\title{
Assessment of 25(OH)D vitamin concentration in plasma of residents of Lodz with metabolic syndrome in pre- and postmenopausal period
}

\author{
Małgorzata Godala ${ }^{1}$, Izabela Materek-Kuśmierkiewicz ${ }^{2}$, Dariusz Moczulski², Ewelina Gaszyńska², \\ Franciszek Szatko3, Sławomir Tokarski ${ }^{4,5}$, Jan Kowalski ${ }^{6}$ \\ ${ }^{1}$ Department of Nutrition and Epidemiology, Chair of Hygiene and Epidemiology, Medical University of Lodz, Poland \\ 2Department of Internal Medicine and Nephrodiabetology, Chair of Internal Diseases and Cardiology, Medical University of Lodz, Poland \\ ${ }^{3}$ Department of Hygiene and Health Promotion, Chair of Hygiene and Epidemiology, Medical University of Lodz, Poland \\ ${ }^{4}$ Faculty of Medicine, University of Rzeszow, Poland \\ ${ }^{5}$ Department of Pulmonology and Allergology, Subcarpatian Centre of Pulmonary Diseases in Rzeszow, Poland \\ ${ }^{6}$ Department of Internal and Infectious Diseases, Medical University of Lodz, Poland
}

\begin{abstract}
Introduction: Vitamin D deficiency is a risk factor for metabolic syndrome disorders and the occurrence of these disorders greatly contributes to the deficiency of vitamin D. Postmenopausal women are particularly prone to that deficiency.

Aim: The aim of the study was to assess vitamin D concentration in the plasma of pre- and postmenopausal women, with or without metabolic syndrome.

Material and methods: The study included 141 women aged 26-77 (the mean age 58.74 years old), divided into 4 groups depending on the pre- or postmenopausal period and diagnosed or not with metabolic syndrome according to the International Diabetes Federation criteria (2005). Vitamin D concentration was assessed by LIAISON ${ }^{\circledast}$ test using chemiluminescent immunoassay (CLIA) technology.

Results: The mean vitamin D concentration was the highest among premenopausal women without metabolic syndrome $(24.32 \mathrm{ng} / \mathrm{ml})$, it was insignificantly higher than in postmenopausal women without metabolic syndrome $(23.52 \mathrm{ng} / \mathrm{ml})$ and significantly higher than in both groups with metabolic syndrome - premenopausal $(19.86 \mathrm{ng} / \mathrm{ml})$ and postmenopausal women $(9.32 \mathrm{ng} / \mathrm{ml})$. The recommended plasma 25(OH)D concentration was not found in any of postmenopausal women with diagnosed metabolic syndrome.

Conclusions: Postmenopausal women with metabolic syndrome had a significantly lower 25(OH)D vitamin concentration in plasma than postmenopausal women without metabolic syndrome. The frequency of vitamin $D$ deficiency in women with metabolic syndrome was very high, significantly higher than in women without metabolic syndrome.
\end{abstract}

Key words: metabolic syndrome, menopause, vitamin D.

\section{Introduction}

Cardiovascular diseases have been the main cause of mortality in Poland for many years, including premature death and the incidence is systematically growing. These diseases contribute to an increase in the number of disabled people and the cost of medical care. The problem of the so-called metabolic syndrome (MS), which includes metabolic risks of atherosclerosis, has been known to doctors for a long time. Results of studies which have been conducted for some years confirm that vitamin D deficiency is a risk factor for MS disorders, including obesity, arterial hypertension, diabetes. On the other hand, there are justified assumptions that these disorders greatly contribute to the deficiency of vitamin $D$ [1-3]. Vitamin $D$ is provided to the body per os and is generated in the skin by ultraviolet radiation $B$ (UVB) [4-6]. Some European population studies demonstrated very low levels of 25 -hydroxyvitamin $\mathrm{D}-25(\mathrm{OH}) \mathrm{D}$ - in the plasma, which confirms an insufficient level of vitamin D in a population, particularly in winter season. Patients with MS are particularly prone to the deficit of vitamin D. In their plasma, the level of $25(\mathrm{OH}) \mathrm{D}$ is lower than in healthy people. This also applies to postmenopausal women, in whom a low level of vitamin D significantly contributes to an increase in the risk of osteoporosis and bone fractures [7-9].

The aim of the study was to assess vitamin D concentration in the plasma of pre- and postmenopausal women, with or without MS. 


\section{Material and methods}

The study included 141 women from Lodz aged 26-77 (the mean age 58.74 years old), divided into following groups:

- group I (control): 24 women before menopause, without MS, aged 26-49 (the mean age 37.83 years old),

- group II (control): 36 women after menopause, without MS, aged 50-65 (the mean age 55.42 years old),

- group III: 30 women before menopause, with MS, aged 38-45 (the mean age 41.95 years old),

- group IV: 51 women after menopause, with MS, aged 56-77 (the mean age 65.52 years old).

General characteristics of study participants are shown in Table I.

The division criteria was the last menstruation which happened at least 12 months before the inclusion in the study. Moreover, the respondents were diagnosed with MS on the basis of the International Diabetes Federation (IDF) criteria. The syndrome included central obesity (waist circumference $>80 \mathrm{~cm}$ ) and at least two more factors: triglyceride concentration $\geq 1.7 \mathrm{mmol} / \mathrm{l}$, $\mathrm{HDL}$ cholesterol level $<1.3 \mathrm{mmol} / \mathrm{l}$, fasting glucose level $\geq 6.1 \mathrm{mmol} / \mathrm{l}$, arterial pressure $\geq 130 / 85 \mathrm{mmHg}$. All the studied women were residents of Lodz, nonsmokers and did not take vitamin supplements in the last year. The study was conducted between January 2012 and April 2013 in the Department of Internal Medicine and Nephrodiabetology, Medical University of Lodz.

Blood for laboratory tests was taken from the basilica vein. The blood samples were used to assess the concentration of $25(\mathrm{OH}) \mathrm{D}$ with the application of the LIAISON $^{\circledR}$ test using chemiluminescent immunoassay (CLIA) technology. The plasma level of 25(OH)D above $30 \mathrm{ng} / \mathrm{ml}$ was considered normal, between $20 \mathrm{ng} / \mathrm{ml}$ and $30 \mathrm{ng} / \mathrm{ml}$ - suboptimal (hypovitaminosis) and below $20 \mathrm{ng} / \mathrm{ml}$ - insufficient (deficiency).

Program Statistica 7.1 PL and Office 2010 were used for statistical purposes. The normal distribution was computed with the Shapiro-Wilk test. If the distribution of at least one variable was different from the normal one, the authors applied the Mann-Whitney's test. In the case of variables with nominal scales, the authors computed the rate of occurrence of the particular feature. For comparative purposes the authors used the $\chi^{2}$ test with Yates' correction. The authors adopted the significance level $p<0.05$.

The Bioethics Committee of Medical University of Lodz gave its consent to such a study to be performed (No. RNN/556/10/KB). All the respondents gave their written consent to be included in the study.

\section{Results}

The range of $25(\mathrm{OH}) \mathrm{D}$ levels in the plasma of women without MS ranged from 11.55 to $53.36 \mathrm{ng} / \mathrm{ml}$ in patients before menopause and from 13.39 to 45.87 $\mathrm{ng} / \mathrm{ml}$ in patients after menopause. In the group of patients with diagnosed MS the levels ranged from 14 to $31 \mathrm{ng} / \mathrm{ml}$ in the group of patients before menopause and $4-17.3 \mathrm{ng} / \mathrm{ml}$ in patients after menopause.

The highest mean concentration of vitamin D was observed in females without MS and before menopause $(24.34 \pm 8.84 \mathrm{ng} / \mathrm{ml})$ and it was insignificantly higher than the mean concentration of vitamin D in postmenopausal women without MS $(23.52 \pm 6.84 \mathrm{ng} /$ $\mathrm{ml}$ ) and significantly higher than in the two remaining groups with diagnosed MS.

The lowest 25(OH)D level was noted in postmenopausal women with diagnosed MS $(9.32 \pm 3.58 \mathrm{ng} / \mathrm{ml})$.

Tab. I. General characteristics of study participants

\begin{tabular}{|c|c|c|c|c|}
\hline \multirow[t]{2}{*}{ Parameters } & Group I & Group II & Group III & Group IV \\
\hline & Mean \pm SD & Mean \pm SD & Mean \pm SD & Mean \pm SD \\
\hline Age (years) & $37.83 \pm 2.6$ & $55.42 \pm 3.5$ & $41.95 \pm 4.6$ & $65.52 \pm 5.2$ \\
\hline $\mathrm{BMI}\left(\mathrm{kg} / \mathrm{m}^{2}\right)$ & $23.42 \pm 2.51$ & $27.26 \pm 4.22$ & $29.68 \pm 4.28$ & $34.26 \pm 5.18$ \\
\hline Waist (cm) & $79.5 \pm 2.6$ & $87.1 \pm 3.5$ & $95.6 \pm 8.9$ & $110.6 \pm 13.3$ \\
\hline Systolic BP (mmHg) & $114.9 \pm 7.9$ & $125.8 \pm 5.6$ & $148.5 \pm 7.2$ & $147.7 \pm 15.6$ \\
\hline Diastolic BP (mmHg) & $80.7 \pm 4.3$ & $89.5 \pm 10.5$ & $90.8 \pm 5.5$ & $98.4 \pm 10.6$ \\
\hline HDL-cholesterol (mmol/l) & $0.98 \pm 0.27$ & $1.05 \pm 0.43$ & $1.07 \pm 0.15$ & $1.15 \pm 0.32$ \\
\hline LDL-cholesterol (mmol/l) & $3.31 \pm 0.49$ & $3.67 \pm 0.56$ & $3.49 \pm 1.78$ & $3.87 \pm 1.14$ \\
\hline Triglycerides (mmol/l) & $1.69 \pm 1.1$ & $1.89 \pm 1.02$ & $2.26 \pm 1.06$ & $2.91 \pm 0.88$ \\
\hline Total cholesterol (mmol/l) & $4.91 \pm 1.45$ & $5.32 \pm 0.89$ & $5.67 \pm 1.24$ & $4.78 \pm 1.22$ \\
\hline Glucose (mmol/l) & $5.17 \pm 0.95$ & $5.21 \pm 0.96$ & $7.01 \pm 0.99$ & $8.08 \pm 3.69$ \\
\hline
\end{tabular}

SD - standard deviation, BMI - body mass index, BP - blood pressure, HDL - high-density lipoprotein, LDL - low-density lipoprotein 
A significantly higher concentration of vitamin $D$ in patients with diagnosed MS was observed in females before menopause rather than after menopause (19.86 \pm $4.78 \mathrm{ng} / \mathrm{ml}$ and $9.32 \pm 3.58 \mathrm{ng} / \mathrm{ml}$, respectively, $p<0.001)$ (Table II).

The highest fraction of patients with the recommended $25(\mathrm{OH}) \mathrm{D}$ concentration in the plasma was observed in females without diagnosed MS before menopause (0.21) significantly more often than in the other groups. In this group every second patient (0.54) was diagnosed with hypovitaminosis and every fourth one (0.25) - vitamin D deficiency.

With regard to women in the post-menopausal period without MS, the recommended $25(\mathrm{OH}) \mathrm{D}$ concentration in the plasma was observed in 0.17 , hypovitaminosis - in 0.47 and vitamin deficiency - in 0.36 .

In the group of women in the pre-menopausal period with MS, the recommended $25(\mathrm{OH}) \mathrm{D}$ concentration was observed only in 0.07 of patients, in 0.4 the authors observed hypovitaminosis and in 0.53 - vitamin D deficiency.

With regard to women with MS after menopause, no woman had the recommended $25(\mathrm{OH}) \mathrm{D}$ concentration or even hypovitaminosis (Table III).

\section{Discussion}

Vitamin D deficiency, which has been mainly considered a risk factor for rickets and osteoporosis, also increases the risk of development of metabolic disorders such as diabetes, arterial hypertension, autoimmune disturbances, and cardiovascular and neoplastic diseases. Pleiotropic activity of vitamin D was observed in molecules, cells, tissues and organs and the vitamin D receptor was already identified in dozens of places in the human body. Thus, meeting demands for vitamin D, diagnosing its deficiency and determining guidelines on supplementation are important steps in management procedures for metabolic syndrome. Females in the post-menopausal period are particularly prone to an increased risk of vitamin D deficiency and its health consequences.

In the conducted study the authors observed a significantly lower level of vitamin $D$ in the plasma of patients with diagnosed metabolic syndrome in comparison to patients without the syndrome, both in the pre- and post-menopausal period. In the group without metabolic syndrome, the $25(\mathrm{OH}) \mathrm{D}$ concentration observed in women in the pre- and post-menopausal period was not significantly different.

In a study conducted by Napiórkowska et al. on 274 elderly females, randomly selected from a general population, the mean concentration of vitamin $D$ was $13.6 \mathrm{ng} / \mathrm{ml}$ [10]. Skalska et al. examined 46 women aged 61-95 years old, in whom the mean 25(OH)D concentration was $15.2 \pm 9.1 \mathrm{ng} / \mathrm{ml}$ [11]. Multicentre studies conducted on 8532 females in the post-menopausal period (the mean age 74.2 years old) in a few European countries showed that the mean $25(\mathrm{OH}) \mathrm{D}$ concentration was $24.4 \mathrm{ng} / \mathrm{ml}$. The lowest level of vitamin D was observed in France $(25.75 \mathrm{ng} / \mathrm{ml})$ and the highest in Spain (34 ng/ml) [12]. Arunbah et al. conducted a study on 410 healthy women aged $20-80$ years old. The results demonstrated that the mean $25(\mathrm{OH}) \mathrm{D}$ concentration was $21.7 \pm 13.8 \mathrm{ng} / \mathrm{ml}$ and it decreased with an increase in the amount of fat tissue [13].

Tab. II. Concentration of 25(OH)D vitamin in plasma $(\mathrm{ng} / \mathrm{ml})$

\begin{tabular}{|c|c|c|c|c|}
\hline & Group I & Group II & Group III & Group IV \\
\hline Range of assessed concentration & $11.55-53.36$ & $13.39-45.87$ & $14-31$ & 4-17.3 \\
\hline Arithmetic mean & 24.34 & 23.52 & 19.86 & 9.32 \\
\hline Standard deviation & 8.84 & 6.84 & 4.78 & 3.58 \\
\hline Median & 23.43 & 22.64 & 19.565 & 8.9 \\
\hline \multicolumn{5}{|c|}{ 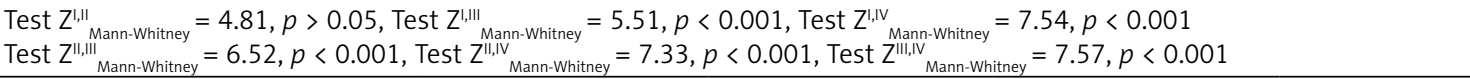 } \\
\hline
\end{tabular}

Tab. III. Structure of $25(\mathrm{OH})$ D vitamin concentration in plasma $(\mathrm{ng} / \mathrm{ml})$

\begin{tabular}{|c|c|c|c|c|}
\hline & Group I & Group II & Group III & Group IV \\
\hline & Fraction $(n)$ & Fraction $(n)$ & Fraction $(n)$ & Fraction $(n)$ \\
\hline 0-20 (deficiency) & $0.25(6)$ & $0.36(13)$ & $0.53(16)$ & $1(51)$ \\
\hline 21-30 (hypovitaminosis) & $0.54(13)$ & $0.47(17)$ & $0.4(12)$ & - \\
\hline 31-80 (recommended level) & $0.21(5)$ & $0.17(6)$ & $0.07(2)$ & - \\
\hline \multicolumn{5}{|c|}{ 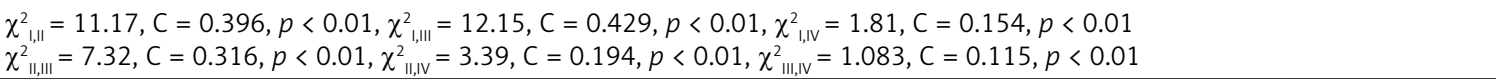 } \\
\hline
\end{tabular}


According to the Third National Health and Nutrition Examination Survey (NHANES), conducted on a representative group of the American population, the mean $25(\mathrm{OH}) \mathrm{D}$ concentration in patients with metabolic syndrome was $26.8 \mathrm{ng} / \mathrm{ml}$. The $25(\mathrm{OH}) \mathrm{D}$ level was statistically lower in patients with diagnosed metabolic syndrome in comparison to the mean level in patients without the syndrome [14]. Botella-Carretero et al. conducted a study on patients with morbid obesity and observed significantly lower levels of vitamin D in the group with metabolic syndrome, whereas such observations were not made in the group without metabolic syndrome [15]. Cigolini et al. conducted a study on patients with type 2 diabetes and noted the mean level of vitamin D of $19.7 \pm 10 \mathrm{ng} / \mathrm{ml}$. The level was significantly lower in comparison to patients without diagnosed type 2 diabetes [16]. Wortsman et al. in their study observed that the mean $25(\mathrm{OH}) \mathrm{D}$ concentration in obese patients was $20.0 \pm 3.4 \mathrm{ng} / \mathrm{ml}$ and it was significantly lower in comparison to patients with normal body weight [17].

Many studies conducted on populations confirm a common deficiency of vitamin $D$ in healthy people. There is a relationship between this deficiency and cardiovascular diseases so it is not surprising that a low concentration of vitamin $D$ in the plasma of patients with metabolic syndrome is very common [18-21]. In their own study the authors observed a deficiency of vitamin D in 0.25 of women in the pre-menopausal period and in 0.36 of women in the post-menopausal period without metabolic syndrome. In the group of females with diagnosed metabolic syndrome, 0.53 of pre-menopausal and all post-menopausal women demonstrated a deficiency of $25(\mathrm{OH}) \mathrm{D}$ in the plasma. With regard to patients with metabolic syndrome, only 0.07 of pre-menopausal women demonstrated the recommended vitamin $D$ concentration in the plasma. The recommended $25(\mathrm{OH}) \mathrm{D}$ concentration was observed significantly more often in women in the pre-menopausal period rather than in the post-menopausal period and also in women without metabolic syndrome rather than in women with such syndrome. Many studies confirm that the deficiency of $25(\mathrm{OH}) \mathrm{D}$ is more frequently found in patients with metabolic syndrome or its some components. Botella-Carretero et al. observed that the frequency of deficiency of vitamin D was significantly higher in obese patients with metabolic syndrome than in obese patients without metabolic syndrome ( $60.9 \%$ vs. $33.3 \%$, respectively) [15]. Similar observations were made in a study conducted by Ford et al. [14]. Lee et al. evaluated a relationship between deficiency of vitamin D and occurrence of myocardial infarction. In this study in only $4 \%$ of patients the recommended $25(\mathrm{OH}) \mathrm{D}$ concentration in the plasma was observed. Seventy-five percent of patients demonstrated a deficiency of vitamin D and another 21\% - hypovitaminosis [22]. Anderson et al. assessed the effect of vitamin D on the development of cardiovascular diseases after analyzing the database of 41504 outpatients, aged 21-55 years old, where the majority were females (74.8\%). They observed a normal level of $25(\mathrm{OH}) \mathrm{D}$ in the plasma of $36 \%$ of the patients; in $47 \%$, the level was decreased $(16-36 \mathrm{ng} / \mathrm{ml})$ and in $17 \%$, the authors observed a deficiency of vitamin $D(<15 \mathrm{ng} / \mathrm{ml})$ [23].

Polish data on deficiency of vitamin $D$ are incomplete. According to data gathered in the OPTIFORD project, conducted in five European countries (including Poland), $90 \%$ of women demonstrate a deficiency of $25(\mathrm{OH}) \mathrm{D}$ in the plasma [10]. A study conducted in a few European countries (including Poland) confirmed that $79.6 \%$ of post-menopausal patients demonstrated a deficiency of vitamin D [10]. Napiórkowska et al. analyzed a population of elderly women and noted a vitamin D deficiency in $83.2 \%$ of them [10]. Skalska et al. observed an abnormal concentration of $25(\mathrm{OH}) \mathrm{D}$ in $87.1 \%$ of elderly patients (the mean age $79.62 \pm 7.4$ years old), of whom the majority were females [11]. Bhattoa et al. examined post-menopausal women from Hungary and observed different levels of a vitamin D deficiency at different times of a year 46.3-71\% [24]. Hill et al. conducted a study on 76 post-menopausal women and observed a low level of $25(\mathrm{OH}) \mathrm{D}$ in the plasma all year round [25]. Lips et al. noted a deficiency of vitamin D in $57.9 \%$ of post-menopausal women [26]. Pfeifer et al. observed in their study a too low level of vitamin D in $91 \%$ of women in the post-menopausal period [27]. Kuchuk et al. evaluated the frequency of insufficient levels of vitamin D in post-menopausal women, affected by osteoporosis. In this group, the level of $25(\mathrm{OH}) \mathrm{D}$ below $20 \mathrm{ng} / \mathrm{ml}$ was observed in $73.5 \%$ of women [28]. Andersen et al. assessed the level of vitamin $D$ in teenagers and elderly women from the north of Europe (Denmark, Finland, Ireland and Poland). The study group included 199 teenagers (the mean age 12.6 years old) and 221 women (the mean age 71.8 years old). Deficiency of vitamin D was observed in $92 \%$ of the studied elderly women and $37 \%$ of the teenage girls [29]. Lucas et al. analyzed a group of 1606 post-menopausal women, inhabitants of warm, sunny countries. They observed sub-optimal concentrations of $25(\mathrm{OH}) \mathrm{D}$ in $58-74 \%$ of the respondents [30].

\section{Conclusions}

Post-menopausal women with diagnosed MS demonstrated significantly lower plasma concentrations of $25(\mathrm{OH}) \mathrm{D}$ than post-menopausal women not affected by that syndrome.

In the group of women without MS, the mean concentration of $25(\mathrm{OH}) \mathrm{D}$ was not significantly different in the pre- and post-menopausal periods.

The occurrence of vitamin D deficiency in the group of women with MS was very high, significantly higher in comparison with women without MS. 


\section{Acknowledgements}

The study was financed by the Medical University of Lodz; research project no. 502-03/6-024-02/502-64-050.

\section{Disclosure}

\section{Authors report no conflicts of interest.}

\section{References}

1. Dąbrowska J, Naworska B, Dąbrowska-Galas M, et al. The role of physical activity in menopause. Prz Menopauzalny 2012; 6: 445-448.

2. Bostick RM, Kushi L, Ying W, et al. Relation of calcium, vitamin D, and dairy food intake to ischemic heart disease mortality among postmenopausal women. Am J Epidemiol 1999; 149: 151-161.

3. Mathieu C, Gysemans C, Giulietti A, et al. Vitamin D and diabetes. Diabetologia 2005; 48: 1247-1257.

4. Płudowski P, Karczmarewicz E, Bayer M, et al. Wytyczne suplementacj witaminą D dla Europy Środkowej: rekomendowane dawki witaminy $D$ dla populacji zdrowej oraz dla grup ryzyka deficytu witaminy D. Endokrynol Pol 2013; 64: 1-9.

5. Pawlak M, Kasprzak JD. Witamina D a rozwój chorób układu krążenia przegląd piśmiennictwa. Pol Prz Kardiol 2011; 13: 114-117.

6. Szczawińska-Popłonyk A, Bręborowicz A. Vitamin D impact on immune functions: implications for preventive strategy of allergic disease? Postep Derm Alergol 2012; 29: 176-181.

7. Lamberg-Allardt C, Brustad M, Meyer HE, et al. Vitamin D - a systematic literature review for the 5 th edition of the Nordic Nutrition Recommendations. Food Nutr Res 2013; 57: 22671-22702.

8. Martineau A, Jolliffe D. Vitamin D and Human Health: from the Gamete to the Grave: Report on a meeting held at Queen Mary University of London, 23rd-25th April 2014. Nutrients 2014; 6: 2759-2919.

9. Kopiczko A. Assessment of intake of calcium and vitamin D and sun exposure in the context of osteoporosis risk in a study conducted on perimenopausal women. Prz Menopauzalny 2014; 13: 79-83.

10. Napiórkowska L, Budlewski T, Jakubas-Kwiatkowska W, et al. Częstość występowania małego stężenia witaminy $D$ w surowicy starszych kobiet w Polsce. Pol Arch Med Wewn 2009; 119: 699-703.

11. Skalska A, Fedak D, Gąsowski J. Stężenie 25-hydroksywitaminy D a stan odżywienia mierzony wskaźnikiem masy ciała u osób starszych. Gerontol Pol 2009; 17: 16-22.

12. Marcinowska-Suchowierska E, Kozłowska-Wojciechowska M, Filipiak KJ. Suplementacja witaminy D u ludzi dorosłych. Terapia 2010; 247: 3-8.

13. Arunbah S, Pollack S, Yeh J, et al. Body fat content and 25-hydroxyvitamin D levels in healthy women. J Clin Endocrinol Metab 2008; 88: 157-161.

14. Ford ES, Ajani UA, McGuire LC, et al. Concentration of serum vitamin D and the metabolic syndrome among U.S. adults. Diabetes Care 2005; 28: $1228-1230$
15. Botella-Carretero JI, Alvarez-Blasco F, Villafruela JJ, et al. Vitamin D deficiency is associated with the metabolic syndrome in morbid obesity. Clin Nutr 2007; 26: 573-580.

16. Cigolini M, Iagulli MP, Miconi V, et al. Serum 25-hydroxyvitamin D3 concentration and prevalence of cardiovascular disease among type 2 diabetic patients. Diabetes Care 2006; 29: 722-724.

17. Wortsman J, Matsuoka LY, Chen TC, et al. Decreased bioavailability of vitamin D in obesity. Am J Clin Nutr 2000; 72: 690-693.

18. John WG, Noonan K, Mannan N, et al. Hypovitaminosis D is associated with reductions in serum apolipoprotein $\mathrm{A}-\mathrm{I}$ but not with fasting lipids in British Bangladeshis. Am J Clin Nutr 2005; 82: 517-522.

19. Makariou S, Liberopoulos E, Florentin M, et al. The relationship of vitamin $D$ with non-traditional risk factors for cardiovascular disease in subjects with metabolic syndrome. Arch Med Sci 2012; 8: 437-443.

20. Chiu KC, Go VLW, Saad MF. Hypovitaminosis D is associated with insulin resistance and cell dysfunction. Am J Clin Nutr 2004; 79: 820-825.

21. Hypponen E, Power C. Hypovitaminosis D in British adults at age $45 \mathrm{y}$ : nationwide cohort study of dietary and lifestyle predictors. Am J Clin Nutr 2007; 85: 860-868.

22. Lee JH, Gadi R, Spertus JA, et al. Prevalence of vitamin D deficiency in patients with acute myocardial acute infarction. Am J Cardiol 2011; 107: 1636-1638.

23. Anderson JL, May HT, Horne BD, et al. Relation of vitamin D deficiency to cardiovascular risk factors, disease status and incident events in a general healthcare population. Am J Cardiol 2010; 106: 963-968.

24. Bhattoa H, Bettembuk P, Ganacharya S, et al. A prevalence and seasonal variation of hypovitaminosis and its relation to bone metabolism in community dwelling postmenopausal women. Osteoporos Int 2004; 15: 447-451.

25. Hill T, McCarthy D, Jakobsen J, et al. Seasonal changes in vitamin D status and bone turnover in healthy Irish postmenopausal women. Int J Vitam Nutr Res 2007; 77: 320-325.

26. Lips P, Duong T, Oleksik A, et al. A global study of vitamin D status and parathyroid function in postmenopausal women with osteoporosis: baseline data from the multiple outcomes of raloxifene evaluation clinical trial. J Clin Endocrinol Metab 2001; 86: 1212-1221.

27. Pfeifer M, Begeroe B, Minne HW, et al. Effects of short-term vitamin D3 and calcium supplementation on blood pressure and parathyroid hormone levels in elderly women. J Clin Endocrinol Metab 2008; 19: 1633 1637.

28. Kuchuk NO, vanSchoor NM, Pluijm SM, et al. Vitamin D status, parathyroid function, bone turnover and BMD in postmenopausal women with osteoporosis: global perspective. J Bone Mineral Res 2009; 24: 693-701.

29. Andersen R, Molgaard C, Skovgaard L, et al. Teenage girls and elderly women living in northern Europe have low winter vitamin D status. Eur J Clin Nutr 2005; 59: 533-541.

30. Lucas J, Bolland M, Grey A, et al. Determinants of vitamin D status in older women living in a subtropical climate. Osteoporos Int 2005; 16 : 1641-1648. 